\title{
Pengembangan Model Mencit Alergi dengan Paparan Kronik Ovalbumin
}

\author{
Wisnu Barlianto*, Mohamad Slamet Chandra Kusuma*, Setyawati Karyono**, Karyono Mintaroem*** \\ *Laboratorium IImu Kesehatan Anak Fakultas Kedokteran Universitas Brawijaya \\ **Laboratorium Farmakologi Fakultas Kedokteran Universitas Brawijaya \\ ${ }^{* * *}$ Laboratorium Patologi Anatomi Fakultas Kedokteran Universitas Brawijaya
}

\begin{abstract}
Histology expression in asthma show inflammatory processes and airway structural changes. Treatment development in asthma needs appropriate animal models but most animal models use short term allergen exposure. The aim of this research was to create develop allergic mouse model with allergic inflammation and structural changes histology expression. Eight female BALB/c mice, 6-12 weeks old, 80-100 grams were divided into two groups. The first group were exposed to a normal saline solution where the second group received ovalbumin. Mice were sensitized by intraperitoneal injection of ovalbumin on day 0 and 14 and challenged by nebulization of $1 \%$ ovalbumin three times weekly for 6 weeks. Twenty four hours after final exposure, the mice were sacrificed by lethal cardiac puncture. The level of total IgE in serum were measured by ELISA and IL-4 receptor expression were examinated by immunohistochemistry. Morphometric analysis was performed to count inflammatory cells, eosinophil, goblet cells, epithel and smooth muscle thickness. Differences between the control and exposed mice were analyzed by MannWhitney test. There were a significant differences in total IgE serum and expression IL-4 receptor between the two groups $(P<0,05)$. The morphometric analyzing also demonstrated significant differences between these two groups $(P<0,05)$. Chronic ovalbumin exposure through inhalation produced allergic inflammation and airway structural changes.
\end{abstract}

Keywords: allergic inflammation, mouse models, chronic exposure, ovalbumin

\section{PENDAHULUAN}

Asma merupakan penyakit inflamasi kronik dinding saluran napas yang ditandai dengan infiltrasi eosinofil dan limfosit. Gambaran histologi asma tidak hanya menunjukan proses inflamasi tetapi juga perubahan struktur saluran napas yang dikenal dengan airway remodeling. Perubahan struktur yang terjadi pada airway remodeling meliputi: hiperplasi dan metaplasi epitel, fibrosis subepitel, hiperplasi dan hipertrofi otot polos, serta peningkatan jumlah pembuluh darah (angiogenesis). Penebalan dinding saluran napas ini diduga berkaitan dengan airway hyperresponsiveness (AHR) dan resistensi terapi serta perburukan asma (1).

Korelasi definitif antara penebalan subepitel atau otot polos saluran napas dan fungsi saluran napas di manusia merupakan suatu hal yang sulit ditunjukan. Bahan pemeriksaan dari manusia untuk mempelajari asma sebagian besar menggunakan hasil biopsi yang terbatas pada lapisan mukosa sehingga tidak dapat melihat perubahan pada struktur yang lebih dalam. Pemeriksaan yang lebih lengkap baru dapat dilakukan pada pemeriksaan post mortem penderita asma (2). Oleh karena itu,penggunaan model binatang yang cocok sangat dibutuhkan dalam mempelajari asthma.

Jurnal Kedokteran Brawijaya, Vol. XXV, No. 1, April 2009; Korespondensi: Wisnu Barlianto, Laboratorium IImu Kesehatan Anak Fakultas Kedokteran Universitas Brawijaya, Telp: 08123319895
Pengembangan terapi asma khususnya untuk mencegah airway remodeling membutuhkan model binatang yang tepat (3). Namun demikian, model binatang yang menunjukan perubahan kronik saluran napas masih belum banyak diteliti, karena sebagian besar model binatang menggunakan paparan alergen yang pendek. Beberapa penelitian dengan paparan alergen kronik gagal menunjukan gambaran inflamasi kronik dan perubahan epitel seperti halnya asma pada manusia. Inflamasi eosinofil dan airway hyperresponsiveness hilang setelah paparan kronik. Hal ini diduga karena adanya toleransi atau desensitisasi terhadap alergen (4). Temelkovsky tahun 1998 berusaha mengatasi keterbatasan ini dengan mengembangkan protokol inhalasi kronik yang menggunakan low-mass-concentration aerosolized antigen. Studi ini menunjukan inflamasi eosinofil kronik dan perubahan epitel di saluran napas, namun kontrol konsentrasi aerosolized antigen ini sangat sulit dilakukan dan tidak reproducible (5). Locke tahun 2007 membandingkan paparan alergen akut, sub akut, dan kronik terhadap terjadinya airway remodeling. Ketiga metode paparan menunjukan terjadinya inflamasi kronik dan fibrosis jalan napas hanya terjadi pada paparan kronik. Tetapi tidak didapatkan perubahan otot polos pada ketiga model paparan (6). Berdasarkan hal di atas, penelitian ini mencoba membuat protokol model mencit alergi yang menunjukan inflamasi kronik dan perubahan struktur saluran napas seperti halnya gambaran asma pada manusia. 


\section{METODE}

Penelitian menggunakan rancangan acak sederhana dengan satu perlakuan, yaitu paparan dengan ovalbumin. Hewan coba yang digunakan adalah $B A L B / c$ mice betina berusia 6-12 minggu (saat awal perlakuan), berat badan 80-100 gram dengan kondisi sehat dan bebas diet ovalbumin. Hewan uji secara acak dibagi menjadi dua kelompok $(p=4)$ yaitu kelompok mencit dengan paparan normal salin (kontrol) dan kelompok mencit dengan paparan ovalbumin.

Alergen yang digunakan berupa ovalbumin chicken (Serva). Sensitisasi awal dilakukan dengan pemberian ovalbumin $10 \mu \mathrm{g}(\mathrm{OVA})$ dan $1 \mathrm{mg} \mathrm{Al}(\mathrm{OH})_{3}$ dalam $0,5 \mathrm{cc}$ normal salin secara intra peritoneal pada hari ke-0 dan 14 . Selanjutnya sensitisasi ulangan diberikan dengan inhalasi ovalbumin $1 \%$ dalam $8 \mathrm{ml}$ normal salin dengan menggunakan nebuliser Omron tipe NU-017 selama 20 menit secara berkala sesuai jadwal seminggu 3 kali selama 6 minggu.

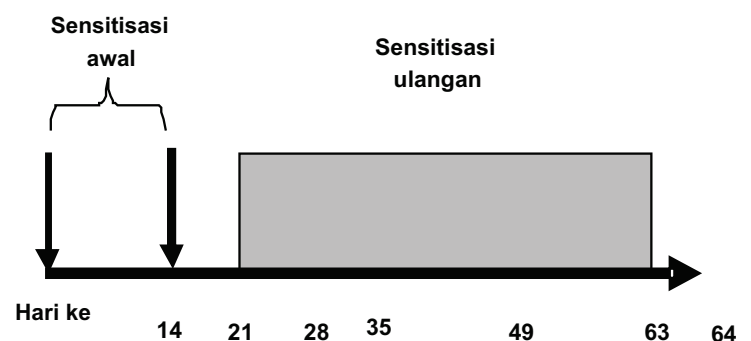

Gambar 1. Protokol Sensitisasi Awal dan Ulangan.

Serum diperoleh dengan lethal cardiac puncture pada mencit yang telah dianestesi 24 jam setelah paparan OVA atau normal salin terakhir. Serum disimpan dalam aliquots $100 \mu \mathrm{l}$ pada suhu $-20^{\circ} \mathrm{C}$ untuk pemeriksaan total IgE dengan ELISA. Jaringan paru difiksasi dengan formalin $10 \%$ selama 24 jam, kemudian dilakukan pembuatan blok parafin dan dilakukan pemotongan dengan mikrometer. Sediaan yang sudah jadi diberi pewarnaan hematoksilin-eosin (HE) untuk pemeriksaan sel inflamasi dan morfometri. Sediaan diamati dengan mikroskop cahaya (Olympus BX51) dengan perbesaran 100x dan 400x sebanyak tiga lapang pandang pada masing-masing sediaan. Gambar difoto dengan menggunakan kamera digital (Olympus DP71). Analisis morfometri untuk perubahan struktur menggunakan Image Pro Plus 6.1 software (Media Cybernetics, Silver Spring, MD). Sedangkan analisis kuantitatif dilakukan dengan melakukan penghitungan jumlah sel goblet, jumlah sel eosinofil dan sel radang peribronkhiolus pada sediaan yang sama di bawah mikroskop cahaya perbesaran $400 x$.

Pengecatan imunohistokimia dilakukan untuk melihat ekspresi reseptor IL-4 dengan menggunakan anti reseptor IL-4 (Cat. \#500706 BioLegend-Antibody primer). Sediaan diamati dibawah mikroskop cahaya dengan pembesaran 1000x. Hasil analisis morfometri, total IgE, dan ekspresi reseptor IL-4 disajikan dalam rerata $( \pm S D)$ untuk setiap kelompok. Uji Mann-Whitney digunakan untuk membandingkan rerata antar kelompok. Analisis statistik menggunakan program SPSS 16.

\section{HASIL}

Kadar IgE serum diukur untuk memastikan telah terjadi sensitisasi yang cukup (Gambar 2). Kadar lgE serum meningkat secara bermakna pada paparan Ovalbumin daripada normal salin $(P<$ $0,05)$.Ekspresi reseptor IL-4 dilihat untuk memastikan inflamasi alergi yang terjadi melalui jalur sel Thelper 2 (Th2) (Gambar 3 dan 4). Ekspresi reseptor IL-4 meningkat pada kelompok yang dipapar dengan ovalbumin $(P<0,05)$.

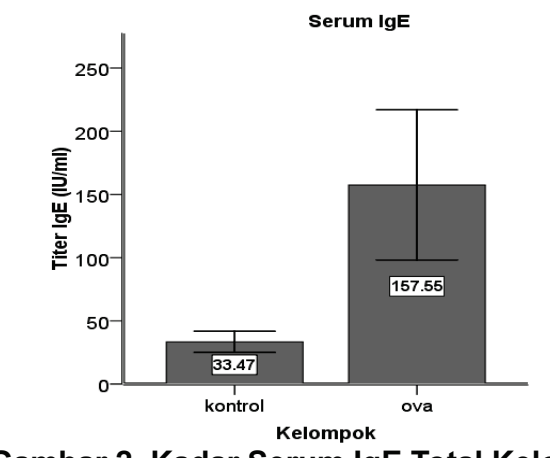

Gambar 2. Kadar Serum IgE Total Kelompok Ovalbumin dan Kontrol

Keterangan: Ekspresi reseptor IL-4 dilihat untuk memastikan inflamasi alergi yang terjadi melalui jalur sel $T$ helper 2 (Th2) (gambar 3 dan 4). Ekspresi reseptor IL-4 meningkat pada kelompok yang dipapar dengan ovalbumin $(P<0,05)$.
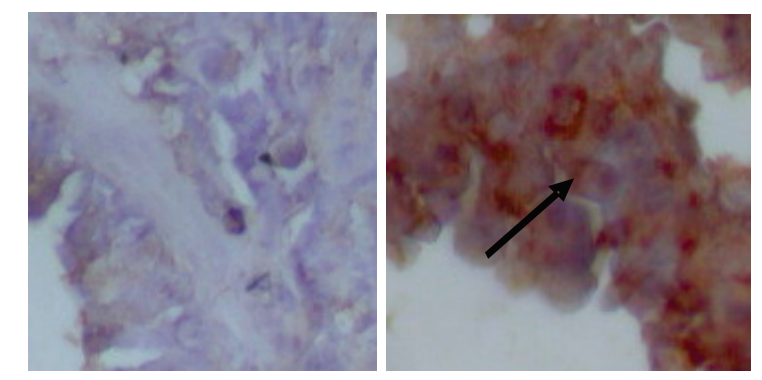

Gambar 3. Gambaran Jaringan Paru dengan Imunohistokimia Anti Reseptor IL-4 (pembesaran 1000X).

Keterangan: Kelompok kontrol (A) dan ovalbumin (B)

$\longrightarrow$ : Ekspresi reseptor IL-4

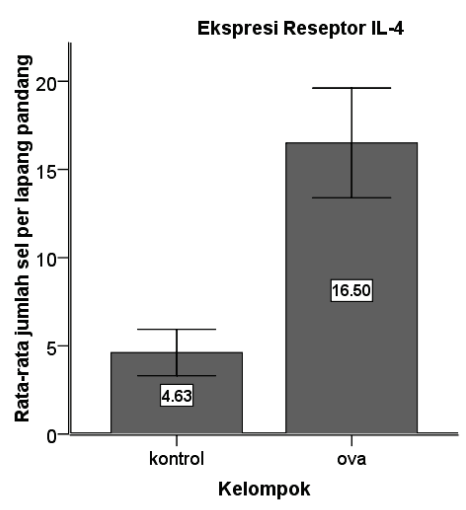

Gambar 4. Ekspresi Reseptor IL-4 Kelompok Ovalbumin dan Kontrol 

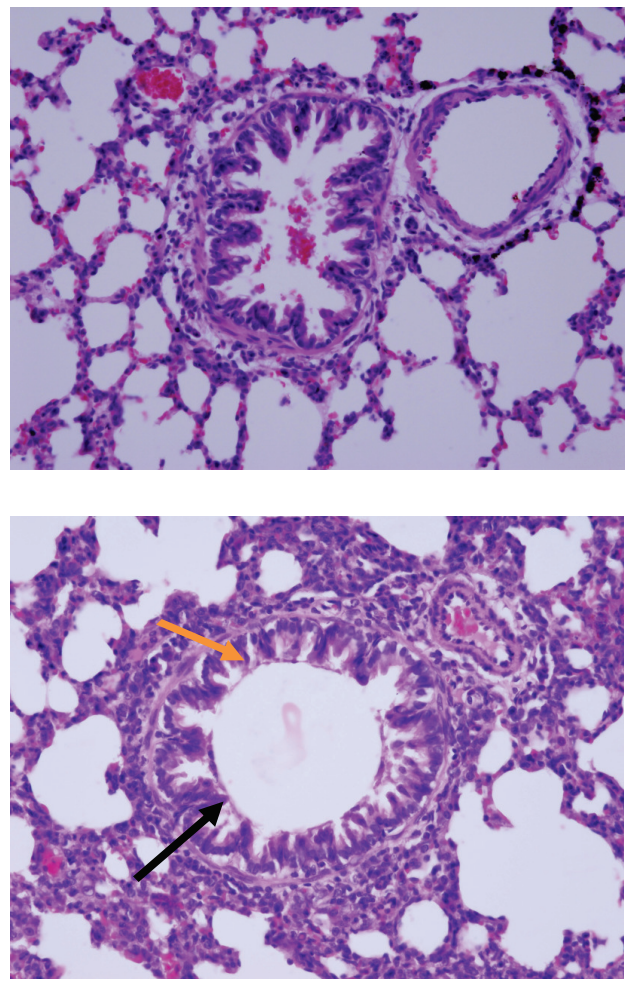

Gambar 5. Gambaran Jaringan Paru dengan Pewarnaan HE pada Kelompok Ovalbumin (Pembesaran 400x).

Keterangan:

A : Kontrol, B : Ovalbumin

$\longrightarrow$ :Penebalan Epitel

$\longrightarrow$ :Penebalan Otot Polos
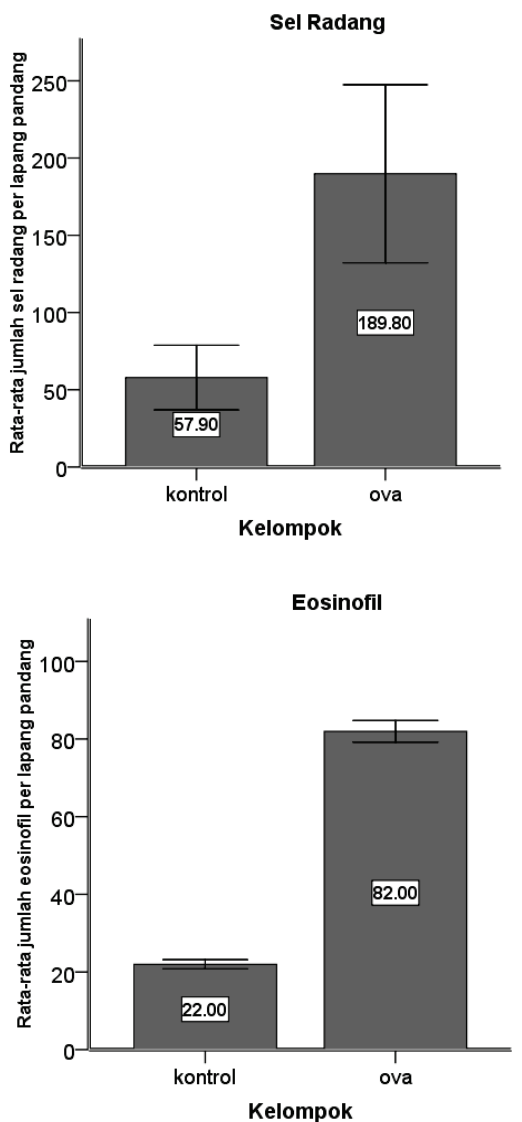

Gambar 6. Perbandingan Infiltrasi Sel Radang (A) dan Eosinofil (B) Peribronkhiolus Antara Kelompok Kontrol dan Ovalbumin

Tabel 1. Perbandingan Jumlah Sel Goblet, Ketebalan Epitel dan Otot Polos antara Kelompok Kontrol dan Ovalbumin

\begin{tabular}{lccc}
\hline & Kontrol (Rerata \pm SD) & Ovalbumin (Rerata \pm SD) & P \\
\hline Jumlah Sel Goblet Per Lapang Pandang & $6,71 \pm 1,77$ & $18,16 \pm 1,97$ & 0,029 \\
Ketebalan Epitel $(\mu \mathrm{m})$ & $89,17 \pm 9,73$ & $109,95 \pm 15,71$ & 0,043 \\
Ketebalan Otot Polos $(\mu \mathrm{m})$ & $2,39 \pm 0,06(\mu \mathrm{m})$ & $3,95 \pm 0,72$ & 0,029 \\
\hline
\end{tabular}

\section{Inflamasi saluran napas}

Respon inflamasi dinilai dengan menghitung jumlah sel radang dan eosinofil peribronkhiolus. Infiltrasi sel radang dan eosinofil lebih tinggi secara bermakna pada kelompok ovalbumin $(P<0,05)$ dibandingkan kontrol (gambar 6).

\section{Airway remodeling}

Perubahan struktur dinding saluran napas seperti: penebalan epitel, hiperplasia sel goblet, dan penebalan otot polos terjadi setelah paparan kronik ovalbumin. Perubahan ini berbeda secara bermakna dibandingkan kelompok kontrol $(P<$ $0,05)$.

\section{DISKUSI}

Penelitian ini menggunakan paparan kronik ovalbumin untuk mendapatkan gambaran inflamasi kronik seperti halnya pada manusia. Paparan kronik ovalbumin menimbulkan inflamasi alergi dan perubahan struktur saluran napas (airway remodeling).

Gambaran karakteristik pada inflamasi alergi adalah dominasi limfosit Th2 dan produk-produknya seperti IL-4, IL-5, dan IL-13. Limfosit T CD4+ yang teraktivasi merekrut sel-sel inflamasi efektor (sel mast, eosinofil dan limfosit) ke jalan napas dan mengendalikan pelepasan mediator-mediator inflamasi dari sel-sel ini. IL- 5 berperan pada aktivasi dan rekrutmen eosinofil ke saluran napas. IL-4 dan IL-13 menginduksi isotype switching kelas IgM menjadi lgE. Crosslinking molekul IgE pada permukaan sel mast menyebabkan degranulasi dan pelepasan mediator-mediator inflamasi tambahan (7).

Pada studi ini didapatkan peningkatan ekspresi reseptor IL-4 yang mencerminkan adanya peningkatan sekresi IL-4. Kadar serum IgE meningkat pada kelompok ovalbumin menunjukan adanya sensitisasi terhadap ovalbumin. Selain itu didapatkan infiltrasi sel radang dan eosinofil yang 
Sesuai dengan gambaran inflamasi alergi. Studi lain menunjukan penurunan infiltrasi eosinofil peribronkhiolus pada paparan kronik ovalbumin (4). Hal ini mungkin disebabkan oleh frekuensi inhalasi ovalbumin yang lebih sering sehingga terjadi toleransi terhadap ovalbumin.

Morfologi saluran napas pada asma tidak hanya menunjukan gambaran inflamasi, tetapi kadangkadang menggambarkan perubahan struktur. Perubahan ini disebut dengan airway remodelling yang memiliki komponen hiperplasi dan metaplasi epitel, fibrosis subepitel, hiperplasi dan hipertrofi otot polos, dan peningkatan pembuluh darah. Airway remodelling terjadi pada trakea, bronkhus, dan bronkhiolus (2).

Episode berulang jejas epitel yang disebabkan inflamasi jalan napas mengakibatkan perpanjangan aktivasi epithelial mesenchymal trophic unit (EMTU) yang akan memicu remodelling jaringan (8). Pada saluran napas penderita asma, terdapat normal upregulation CD44 dan ekspresi epidermal growth factor receptor (EGFR) yang dipicu oleh kerusakan epitel jalan napas, tetapi peningkatan ekspresi EGFR ini tidak menyebabkan perbaikan epitel yang sempurna. Selanjutnya terjadi proses perbaikan sekunder yang menyebabkan peningkatan deposisi protein matriks ekstra seluler. Sel epitel yang teraktivasi mensekresi fibrogenic growth factor termasuk TGF 1, TGF 2, basic fibroblast growth factor (bFGF), epidermal growth factor (EGF), endothelin dan insulin growth factor yang semuanya bekerja untuk memicu proliferasi miofibroblas dan peningkatan produknya berupa matriks protein (9). Sel epitel paru yang teraktivasi dan fibroblas juga menunjukkan peningkatan ekspresi integrins 516 (10), yang memfasilitasi akumulasi subepitel fibronectin dan tenascin, juga memicu migrasi dan diferensiasi fibroblas (11). Selama proses perbaikan, sel-sel epitel dan subepitel mengekspresikan IL-11 yang berkorelasi dengan deposisi luas kolagen tipe I dan III (12). Selain itu terjadi juga peningkatan regulasi dan hipersekresi mucin keluarga MUC (MUC5B dan MUC5AC lebih dari tipe MUC2) yang dapat menyebabkan hiperplasia dan metaplasia sel mukous dan penebalan epitel (13).

Paparan kronik ovalbumin pada studi ini menyebabkan perubahan struktur saluran napas berupa penebalan epitel, peningkatan sel goblet, dan penebalan otot polos. Hasil ini sesuai dengan penelitian yang dilakukan oleh Temelkovski dan Locke $(5,6)$, namun kedua studi tersebut tidak berhasil menunjukan perubahan pada otot polos. Perbedaan metode dan alat mungkin menyebabkan perbedaan ini. Penebalan lapisan otot polos saluran napas merupakan satu dari perubahan-perubahan yang ditemukan selama airway remodeling pada asma. Hipertropi dan hyperplasia keduanya diyakini sebagai penyebab peningkatan volume otot polos saluran napas pada asma $(14,15,16)$.

Studi ini tidak memeriksa sitokin dan mediator inflamasi yang berperan pada airway remodeling. Pemahaman tentang peranan sitokin dan mediator inflamasi pada konsep airway remodeling dapat menjadi titik awal pengembangan terapi asma untuk mencegah airway remodeling.

\section{KESIMPULAN}

Paparan kronik ovalbumin secara inhalasi pada model binatang alergi menyebabkan inflamasi alergi dan perubahan struktur saluran napas. Perubahan struktur saluran napas menunjukan airway remodeling seperti gambaran asma pada manusia

\section{DAFTAR KEPUSTAKAAN}

1. Bousquet J, Jeffery PK, Busse WW, Johnson M, Vignola AM. Asthma: from bronchoconstrictions to airways inflammation and remodeling. Am J Respir Crit Care Med. 2000; 161:1720-45

2. Tang MLK, Wilson JW, Stewart AG, Royce SG. Airway remodelling in asthma: Current understanding and implications for future therapies. Pharmacology \& Therapeutics. 2006; 112:474488

3.Redington AE. Fibrosis and airway remodeling. Clin Exp Allergy. 2000; 30:42-5

4. Shinagawa K, Kojima M. Mouse model of airway remodeling: Strain differences. Am J Repir Crit Care Med. 2003; 168:959-67

5. Temelkovski J, Hogan SP, Shepherd DP, Foster PS, Kumar R. An improved murine model of asthma: selective airway inflammation, epithelial lesions and increased methacholine responsiveness following chronic exposure to aerosolised allergen. Thorax. 1998; 53:849-56

6. Locke NR, Royce SG, Wainewright JS, Samuel CS, Tang ML. Comparison of airway remodeling in acute, subacute, and chronic models of allergic airways disease. Am J Respir Cell Mol Biol. 2007; 36:625-32

7. Akers IA, Parsons M, Hill MR, Hollenberg MD, Sanjar S, Laurent GJ, et al. Mast cell tryptase stimulates human lung fibroblast proliferation via protease-activated receptor-2. Am J Physiol Lung Cell Mol Physiol. 2000;278: 193-201

8.Phipps S, Benyahia F, Ou TT, Barkans J, Robinson $\mathrm{DS}$, Kay AB. Acute allergen-induced airway remodeling in atopic asthma. Am J Respir Cell Mol Biol. 2004;31: 626-32.

9. Holgate S, Lackie P, Davies DE, Roche RW, Walls AF. The bronchial epithelium as a key regulator of airway inflammation and remodeling in asthma. Clin Exp Allergy .1999; 29: 90.

10.Sheppard D. Airway epithelial integrins: why so many?. Am J Respir Cell Mol Biol. 1998; 19:349351.

11.Knight D. Epithelium-fibroblast interactions in response to airway inflammation. Immunol Cell Biol . 2001; 160-164.

12.Minshall EM, Chakir J, Laviolette M, Molet S, Zhu 
$\mathrm{Z}$, Olivenstein R, et al. IL-11 expression is increased in severe asthma: association with epithelial cells and eosinophils. J Allergy Clin Immunol. 2000;105: 232-38.

13.Fedorov I, Wilson S, Davies D, Holgate S. Epithelial stress and structural remodelling in childhood asthma. Thorax. 2005;60:389-394.

14.Ebina M, Takahashi T, Chiba T, Motomiya M. Cellular hypertrophy and hyperplasia of airway smooth muscles underlying bronchial asthma. A 3-D morphometric study (abstract). Am Rev Respir Dis. 1993; 148: 720-726.

15.Benayoun L, Druilhe A, Dombret MC, Aubier M, Pretolani M. Airway structural alterations selectively associated with severe asthma. Am J Respir Crit Care Med. 2003;167: 1360-1368.

16. Woodruff PG, Dolganov GM, Ferrando RE, Donnelly S, Hays SR, Solberg OD, et al. Hyperplasia of smooth muscle in mild to moderate asthma without changes in cell size or gene expression. Am J Respir Crit Care Med. 2004; 169: 1001-1006. 